\title{
PENGEMBANGAN SUMBER DAYA MANUSIA DALAM PENINGKATAN MUTU LULUSAN PADA LEMBAGA PENDIDIKAN ISLAM DI KABUPATEN LAMPUNG SELATAN
}

\author{
Andi Warisno \\ IAI Annur Lampung \\ stai_annur10@yahoo.com
}

\begin{abstract}
The problem facing the madrasa today, is that there are still very fundamental internal problems, in all the education system, especially the management system and a low work ethic, the quality and quantity of inadequate Educators, ineffective curricula, and physical facilities and facilities that are still not enough. Because these factors make the madrasa receive less response from the community, so that its existence becomes marginalized from the world of education. Although many problems arise from the implementation of the Islamic education system in the madrasa as mentioned above, there are several Islamic education institutions (madrasas) in South Lampung that it turns out that it can be considered superior and able to compete with other advanced school institutions - even some of the madrassas are much in demand by the public even though they are private, namely MTs Mathla'ul Anwar Cintamulya, MTs. Hidayatul Mubtadii Jati Agung and MTs. Al Ishlah Sukadamai Natar. Research in three madrasa institutions, this study produced several findings, namely, that first, Educator resource development is based on self-evaluation and needs analysis, program preparation, program implementation; Conduct implementation evaluation; Achievement target; and Orientation of resource development Educators for madrasas. Second, the Educator HR development strategy starts from the "buy" (recruitment) and "make" (coaching / development) process. Third, the form of activities in the context of educating / developing HR Educators is carried out correctly and systematically according to quality standards. Likewise with the development of educational resources (employees) carried out by: planning, training and development, assessment of the percentage of work, employee reward / career planning. The HR development strategy of employees is almost the same as Educators, which starts from the process of "buy" (recruitment) and "make" (coaching / development), which is then carried out correctly and systematically in accordance with quality standards. can be achieved if HR (Educators and Education staff) are optimized through reliable management.
\end{abstract}

Keywords: Islamic Education Institutions, Human Resources, Quality Improvement of Graduates.

\begin{abstract}
Abstrak
Problema yang dihadapi madrasah saat ini, adalah masih adanya permasalahanpermasalahan internal yang sangat fundamental, pada seluruh sistem kependidikannya, terutama sistem manajemen dan etos kerja yang rendah, kualitas dan kuantitas Pendidik yang kurang memadai, kurikulum yang tidak efektif, dan sarana fisik serta fasilitas yang masih belum cukup. Karena faktor-faktor tersebut menjadikan madrasah kurang mendapat respon dari masyarakat,sehingga eksistensinya menjadi termarginalkan dari dunia pendidikan.Meskipun banyak persoalan yang muncul dari penyelenggaraan sistem pendidikan Islam di madrasah sebagaimana tersebut di atas, ada beberapa lembaga pendidikan Islam (madrasah) di Lampung Selatan yang ternyata dapat dianggap unggul dan mampu bersaing dengan lembaga sekolah maju lainnya, bahkan beberapa madrasah tersebut banyak diminati
\end{abstract}


oleh masyarakat meski berstatus swasta yaitu MTs Mathla'ul Anwar Cintamulya, MTs. Hidayatul Mubtadii Jati Agung dan MTs. Al Ishlah Sukadamai Natar. Penelitian di tiga lembaga madrasah, penelitian ini menghasilkan beberapa temuan, yaitu, bahwa pertama, Pengembangan sumber daya Pendidik didasarkan pada Evaluasi diri dan analisis kebutuhan;penyusunan program;pelaksanaan program; Melakukan Evaluasi pelaksanaan; Target pencapaian; dan Orientasi pengembangan sumberdaya Pendidik bagi madrasah. Kedua, Strategi pengembangan SDM Pendidik dimulai dari proses "buy" (rekrutmen) dan "make" (pembinaan/pengembangan). Ketiga, Bentuk kegiatan dalam rangka pembinaan/pengembangan SDM Pendidik dilakukan dengan benar dan sistematis sesuai standar mutu. Begitu pula dengan pengembangan sumber daya Kependidikan (pegawai) dilakukan dengan : perencanaan, latihan dan pengembangan, penilaian persentasi kerja, pemberian imbalan/perencanaan karier pegawai. Adapun strategi pengembangan SDM pegawai hampir sama dengan Pendidik, yakni dimulai dari proses "buy" (rekrutmen) dan "make" (pembinaan/pengembangan), yang selanjutnya pembinaan dilakukan dengan benar dan sistematis sesuai standar mutu.Berdasarkan hasil penelitian dapat disimpulkan pulapeningkatan mutu lulusan dapat tercapai jika SDM (Pendidik dan tenaga Kependidikan) dioptimalkan melalui manajemen yang andal.

Kata Kunci: Lembaga Pendidikan Islam, Sumber Daya Manusia, Peningkatan Mutu Lulusan.

\section{Pendahuluan}

Proses pembangunan sebuah bangsa pada hakikatnya diarahkan untuk membangun manusia seutuhnya, baik moral maupun material. Membangun manusia yang bermoral berarti membangun kualitas bangsa. John Gardner, mengatakan bahwa suatu bangsa akan menjadi besar apabila bangsa itu percaya pada sesuatu itu harus berdimensi moral, sesuatu yang berdimensi moral tidak lain adalah bersumber dari ajaran agama. ${ }^{1}$

Agama akan membentuk manusia bermoral apabila dilakukan melalui jalur proses pendidikan (Pendidikan Agama Islam). Sebagaimana dijelaskan dalam Al Qur'an Surat Al Mujadilla ayat 11:

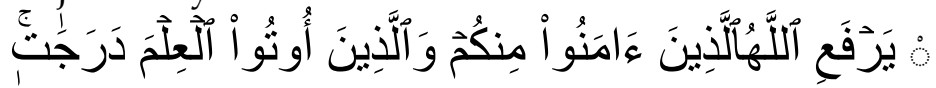

Artinya : Allah akan meninggikan orang-orang yang beriman di antaramu dan orang-orang yang diberi ilmu pengetahuan beberapa derajat. ${ }^{2}$

Mastuhu juga berpendapat bahwa manusia adalah makhluk yang memiliki daya akal dan kehidupan baik. Ia harus membentuk peradaban dan menujukkan kehidupan melalui proses pendidikan (belajar mengajar) ${ }^{3}$.

Proses pendidikan merupakan upaya penanaman dan pewarisan nilai-nilai budaya untuk mengembangkan potensi manusia, serta sekaligus proses produksi nilai-nilai budaya baru sebagai hasil interaksi potensi dengan konteks

1Dalam Nurcholish Madjid, Islam Doktrin dan Peradaban. (Jakarta: Yayasan Wakaf Paramadina,1993), h. xx

2Departemen Agama RI, Al Qur'an dan Terjemahnya. (Surabaya: Mahkota, Edisi Revisi, 2013), h. 465

3Mastuhu, Dinamika Sistem Pendidikan Pesantren (Jakarta: INIS, 1994), h. 1 
kehidupan. Ahmad Tafsir menjelaskan bahwa pendidikan adalah proses pengembangan pribadi manusia dalam semua aspeknya. ${ }^{4}$

Pendidikan Islam di Indonesia sebagai sub sistem pendidikan nasional, pada hakikatnya juga bertujuan untuk berpartipasi dalam membangun kualitas sumber daya manusia bangsa dalam segala aspeknya, terutama sekali dalam hal peningkatan moral serta kesejahteraan di masa yang akan datang. Dalam Al Qur'an Surat An Nisa ayat 9, Allah menjelaskan :

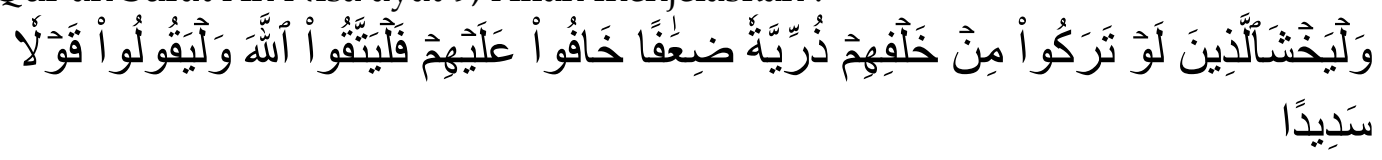

Artinya: Dan hendaklah takut kepada Allah orang-orang yang seandainya meninggalkan dibelakang mereka anak-anak yang lemah, yang mereka khawatir terhadap (kesejahteraan) mereka. Oleh sebab itu hendaklah mereka bertakwa kepada Allah dan hendaklah mereka mengucapkan perkataan yang benar. ${ }^{5}$

Namun demikian dalam proses penyelenggaraannya, Pendidikan Islam telah diatur oleh pemerintah melalui jalur formal, non formal dan Informal. ${ }^{6}$

Malik Fadjar dalam menangkap makna dari dua jalur pendidikan tersebut telah memetakan tiga jenis penyelenggaraan pendidikan Islam di Indonesia. Pertama, Jenis pendidikan yang pendirian dan penyelenggaraannya didorong oleh semangat dan cita-cita utuk mewujudkan nilai-nilai Islam, baik yang tercermin dalam lembaga maupun dalam bentuk kegiatan-kegiatan. Di sini kata Islam ditempatkan sebagai sumber nilai yang diwujudkan dalam seluruh aktifitas. Kedua, jenis pendidikan yang dalam penyelenggaraannya hanya menjadikan Islam sebagai bahan studi atau bahan kajian. Ketiga, jenis pendidikan yang dalam penyelenggaraannya menjadikan Islam sebagai bahan studi sekaligus sebagai nilai dan semangat cita-cita Islam. ${ }^{7}$

Jenis penyelenggaraan pendidikan Islam yang kedua, seperti ditawarkan Malik Fadjar di atas, nampaknya mendapat perhatian yang cukup besar dari pemerintah melalui jalur sekolah formal, yang dalam hal ini menjadi dua lembaga operasional yaitu sekolah umum dan madrasah. Dalam konteks ini,

${ }^{4}$ Kata pengembangan menurut Ahmad Tafsir dapat diartikan : Pertama, ada kegiatan pendidikan yang bisa dilakukan oleh diri sendiri, orang lain (pendidik) dan oleh lingkungan sekitar. Kedua, tempat pendidikan, yaitu dalam keluarga, masyarakat dan di sekolah. Ketiga, ada objek binaan pendidikan yaitu peserta didik (meliputi jasmani dan ruhaninya). Sisi lain, Tafsir menjelaskan bahwa, pendidikan oleh diri sendiri dan lingkungan sekitar, nampaknya sulit untuk dirancang atau direkayasa, dan teori-teori mengenai hal itu belum banyak dikembangkan oleh para ahli. Akan tetapi pendidikan oleh orang terhadap orang lain, secara relatif mudah direkayasa atau diformat dalam bentuk program. Demikian juga dalam persoalan tempat pendidikan agaknya yang paling mudah dilaksanakan adalah melalui jalur yang terlembagakan,baik jalur sekoalahformal maupun luar sekolah non-formal.Lihat Ahmad Tafsir, Ilmu Pendidikan Dalam Perspektif Islam. ( Bandung: Remaja Rosydakarya, 1992), h. 26-28.

${ }^{5}$ Departemen Agama RI. , h. 124

6Undang-undang Nomor 20 tahun 2003. tentang sistem pendidikan Nasional, (Bandung: Citra Umbara, 2003), Pasal 13.

7Malik Fadjar, Tantangan dan Peran Umat Islam Dalam Menyongsong Abad XXI. (Surabaya: Makalah IAIN Sunan Ampel,1995), h. 2. 
Karel A. Steenbrink telah memetakan dan membuat kategori tersendiri antara madrasah dan sekolah, sebagaimana disebutkan:

Istilah madrasah dengan sekolah sangat berbeda, karena sekolah identik dengan adopsi model barat, sedangkan madrasah adalah khas lembaga pendidikan dalam Islam, yang perlu digaris bawahi dalam hal ini bahwa, kedua lembaga tersebut masuk dalam katagori jalur pendidikan formal, yang pada hakikatnya sama-sama ingin melaksanakan pembinaan dan peningkatan sumber daya manusia atau kualitas manusia Indonesia secara utuh demi tercapainya tujuan pembangunan nasional tersebut. Dan secara terus menerus kedua lembaga tersebut juga dikembangkan untuk melayani kebutuhan pembangunan dan kemajuan ilmu pengetahuan dan teknologi bagi masyarakat,atau dengan kata lain kedua lembaga tersebut dikembangkan agar mampu menghadapi tantangan zamannya. ${ }^{8}$

Melalui pendidikan, diharapkan dapat meningkatkan kualitas kehidupan pribadi dan masyarakat. Muhaimin ${ }^{9}$ menyatakan bahwa pendidikan dalam makna filosofisnya adalah upaya mempercepat dan menyertai perubahan serta perkembangan umat manusia dengan cara menghantar dan membimbing perubahan dan sekaligus mengarahkan kehidupan manusia itu sendiri. Mengingat pentingnya fungsi dan tujuan pendidikan juga telah dinyatakan dalam Undang-Undang Nomor 20 tahun 2003 tentang sistem Pendidikan Nasional, sebagai berikut:

"Pendidikan Nasional berfungsi mengembangkan kemampuan dan membentuk watak serta peradaban bangsa yang bermartabat dalam rangka mencerdaskan kehidupan bangsa, bertujuan untuk berkembangnya potensi peserta didik agar menjadi manusia yang beriman dan bertaqwa kepada Tuhan Yang Maha Esa, berakhlak mulia, sehat, berilmu, cakap, kreatif, mandiri, yang menjadi warga negara yang demokratis serta tanggung jawab."10

Agar tujuan pendidikan dapat dicapai, maka pendidikan hendaknya dikelola secara profesional dengan manajemen yang baik dan oleh tenagatenaga yang mempunyai motivasi kerja tinggi, termasuk di dalamnya adalah lembaga pendidikan Islam (madrasah). Sebagaimana diketahui bahwa salah satu prioritas pembangunan pendidikan nasional dalam kaitanya dengan pengembangan kualitas sumber daya manusia ialah menyangkut peningkatan mutu setiap jenis dan jenjang pendidikan. Seiring dengan kehidupan dinamis masyarakat, maka pendidikan harus selalu dikembangkan, agar peserta didik dapat mengikuti perkembangan dan perubahan masyarakat. Dengan kata lain pendidikan perlu dikembangkan sepanjang hidup (Long life education).

${ }^{8}$ Karel A.Steenbrink, Pesantren, Madrasah, Sekolah: Pendidikan Islam Dalam Kurun Modern (Jakarta : LP3ES, 1986), h. 89-128.

${ }^{9}$ Muhaimin, Konsep Pendidikan Islam: Sebuah Telaah Komponen Dasar Kurikulum. (Solo: Ramadhoni, 1991), h. 9

10Undang-Undang Nomor 20 tahun 2003, tentang sistem pendidikan..., pasal 3. 
Pandangan pokok mengenai proses pendidikan sepanjang hidup adalah berlangsung di jalur formal, informal, maupun non formal, dimana manusia itu hidup. Lembaga pendidikan Islam (Madrasah) masuk dalam katagori lembaga pendidikan formal dan sangat memungkinkan untuk dapat dijadikan sebagai proses pengembangan kualitas sumber daya manusia Indonesia. ${ }^{11}$

Madrasah merupakan lembaga pendidikan Islam khas milik umat Islam, dan lahir dari proses sejarah yang panjang. Lembaga pendidikan madrasah tersebut telah digunakan oleh umat Islam Indonesia, untuk mempelajari berbagai ilmu, dan keberadaannya merupakan bagian dari perkembangan kehidupan umat Islam sepanjang sejarah, terutama di wilayah Nusantara. ${ }^{12}$

Suatu lembaga pendidikan (Sekolah/Madrasah) pada dasarnya adalah upaya kelembagaan dan formalisasi pendidikan sehingga kegiatan,fungsi,dan proses pendidikan dalam suatu masyarakat bisa berlangsung secara lebih terencana, sistematis, berjenjang dan profesional. ${ }^{13}$ Kehadiran lembaga pendidikan formal seperti madrasah, sepanjang sejarahnya tidak terlepasdari kepentingan untuk memenuhi kebutuhan masyarakat dan negara, dimana lembaga pendidikan tersebut diselenggarakan. Karena "From the beginning, it appears that school and their skilled products were seen as serving the state and society as a whole" ${ }^{14}$ Dalam kontek ini, lembaga pendidikan formal ( sekolah/madrasah ) bisa dianggap sebagai sebagai instrumen nasional dalam memberikan pelayanan kepada masyarakat melalui kegiatan pendidikan untuk memenuhi harapan dan cita-cita kehidupan masyarakat dan negara di mana lembaga itu berada. Keberadaan madrasah sebagaimana wujudnya sekarang ini, merupakan hasil dari sebuah proses pemikiran tentang model pendidikan yang dilakukan dalam waktu yang relatif lama. Dahlan Hasim ${ }^{15}$ menjelaskan bahwa selama hampir satu abad, yaitu sejak di rintis oleh Abdullah Ahmad dengan Madrasah Adabiyahnya di Padang Panjang pada tahun 1907 sampai sekarang, madrasah telah menjalani pilarisasi pengembangan seiring dengan tuntutan zamannya.

Dalam perspektif historis, keberadaan lembaga pendidikan formal seperti madrasah sekarang ini, merupakan akumulasi berbagai macam budaya dan tradisi pendidikan yang berkembang di masyarakat Indonesia. Mulai dari tradisi pra-sejarah atau tradisi asli, tradisi Hindu Budha, tradisi Islam, dan tradisi Barat atau modern. ${ }^{16}$ Oleh sebab itu, madrasah telah menjadi salah satu wujud identitas budaya bangsa Indonesia yang telah menjalani proses

11Ahmad Fatah Yasin, Dimensi-dimensi Pendidikan Islam, (Malang: UIN Press, 2008), h. 257274.

${ }^{12}$ Hasbullah, Sejarah Pendidikan Insilam di Indonesia:Lintasan Sejarah Pertumbuhan dan perkembangan, (Jakarta:Raja Grafindo persada, 1996), h. 66

${ }_{13}$ Yahudi Cohen, School and Civilationl States (New York: Internasional Texbook Company Pergamon Press,1970), h. 56.

14Ingemar Fagerlind \& Lawrence J. Saha, Education and National Develoment: A Comperative Perspektive (New York : Pergamon Press,1983), h. 32.

15Malik Fadjar, Madrasah dan Tantangan Mordernitas (Bandung: Mizan, 1998) h. vii. 16Ibid, h.19. 
sosialisasi yang relatif intensif, dan dalam waktu yang cukup panjang itu telah memainkan peran tersendiri dalam panggung pembentukan peradaban bangsa.

Namun dalam kenyataannya, lembaga-lembaga pendidikan Islam, seperti pesantren, madrasah, dan sekolah-sekolah Islam, pada awalnya kurang mendapatkan perhatian dari masyarakat, terutama kelompok masyarakatmasyarakat menengah atas. Hal ini disebabkan karena lembaga-lembaga pendidikan tersebut dianggap belum mampu mengakomodasi kepentingan dan tuntutan masyarakat terkait dengan perkembangan peserta didik untuk persiapan hidup di masa depannya. Apalagi keberadaan lembaga pendidikan madrasah tersebut, sejak lahir dan berkembangnya, umumnya berada di wilayah pedesaan, yang apabila dicermati mayoritas penduduk pedesan berekonomi kelas bawah dengan pola kehidupan bercocok tanam (pertanian). Di wilayah perkotaan justru madrasah pada mulanya sulit untuk bisa berkembang atau dengan kata lain kurang diminati masyarakat. Oleh karena itu, apabila berbicara tentang madrasah berarti berbicara tentang tradisi kehidupan orang desa.

Problema lain yang dihadapi madrasah, adalah masih adanya permasalahan-permasalahan internal yang sangat fundamental, seperti dikatakan Malik Fadjar bahwa:

Problem yang dihadapi madrasah meliputi seluruh sistem kependidikannya, terutama sistem manajemen dan etos kerja yang rendah, kualitas dan kuantitas pendidik yang kurang memadai, kurikulum yang tidak efektif, dan sarana fisik serta fasilitas yang masih belum cukup. Karena faktor-faktor tersebut menjadikan lembaga pendidikan Islam, seperti madrasah ditinggalkan oleh masyarakat, kurang mendapat respon dari masyarakat. sehingga eksistensinya menjadi termarginalkan dari dunia pendidikan masyarakat. ${ }^{17}$

Di samping itu ketertinggalan madrasah selama ini, juga dilatarbelakangi oleh tiga faktor penting yaitu: Pertama, tradisi yang dikembangkan masih berorientasi ke masa silam yang berciri konservatisme. Kedua, mutu penyelenggaraan yang sangat rendah sehingga profesionalisme tidak jelas. Ketiga, relevansi pendidikan Islam yang kurang mampu merespon tuntutan perkembangan baru yang riil. ${ }^{18}$

17Ibid, h. 41. Aspek Kemampuan, Semangat Komitmendan disiplin sumber daya manusia ( tenaga pendidik) sebagai penentu kualitas pendidikan di madrasah juga sering menjadi bahan kritik para ahli pendidikan lihat :Mulyasa, Manajemen Berbasis Sekolah, Konsep, Stategi dan Implementasi, (Bandung: Remaja Rosydakarya,2002), h. 3. Lihat juga, Azra, Pendidikan Islam: Tradisi Mordernisasi Menuju Melanium Baru, (Jakarta: Logos, 1999), h. 80

${ }^{18}$ Koran Pendidikan, $21 / 8 / 2004$ 


\section{Konsep Tentang Madrasah}

Kata "madrasah" diambil dari kata "darasa" yang berarti belajar. Madrasah adalah ism makân dari kata ini sehingga berarti tempat untuk belajar. ${ }^{19}$ Istilah madrasah sering diidentikkan dengan sekolah atau instusi umat Islam. ${ }^{20}$ Sebagai tempat belajar, maka madrasah berfungsi sebagai wahana atau tempat untuk mengembangkan kepekaan intelektual dan informasi, memperbaharui pengetahuan, serta membentuk sikap dan ketrampilan yang berkelanjutan agar tetap up to date dan tidak cepat usang. ${ }^{21}$ Malik Fadjar juga menjelaskan bahwa madrasah berasal dari bahasa Arab. Secara harfiah, kata ini berarti atau setara maknanya dengan kata Indonesia "sekolah", yang nota bene juga bukan kata asli dari bahasa kita, "sekolah" dialihkan dari bahasa asing, misalnya school ataupun scola. ${ }^{22}$

Madrasah mengandung arti tempat atau wahana seseorang mengenyam proses pembelajaran. Maksudnya, di madrasah itulah siswa menjalani proses belajar secara terarah, terpimpin, dan terkendali. Dengan demikian, secara teknis madrasah menggambarkan proses pembelajaran secara formal yang tidak berbeda dengan sekolah. Hanya dalam lingkup kultural, madrasah memiliki konotasi spesifik. Di lembaga ini siswa mempelajari hal ihwal ilmu dan tradisi keagamaan, dan ilmu-ilmu lain yang diperlukan oleh peserta didik sesuai dengan tuntutan kehidupan masyarakat, bangsa dan negara. Meskipun pada awalnya madrasah dikenal hanya sebagai wahana tempat mempelajari ilmuilmu keagamaan, namun dalam perkembangannya madrasah telah menampilkan diri sebagai lembaga pendidikan yang mempelajari berbagai ilmu yang berkembang di dunia persekolahan pada umumnya.

\section{Madrasah Sebagai Institusi Pendidikan Islam.}

Mengembangkan pendidikan Islam berarti mendidik atau menginternalisasikan ajaran Islam kepada manusia dengan tidak ada batasan selesainya dan agar sesuai dengan konteks zaman. Ajaran Islam tidak hanya membicarakan aspek ubudiyyah melainkan juga aspek-aspek mu'amalah yang apa bila dipetakan dalam kajian keilmuan sangatlah luas. Aspek-aspek ubudiyah biasanya dibahas dalam kajian ilmu-ilmu agama (Islam), sedangkan aspek muamalah biasanya dibahas dalam kajian ilmu-ilmu sosial dan kealaman. Namun demikian, secara luas ilmu-ilmu keislaman itu pada hakikatnya adalah mencakup didalamnya ilmu-ilmu apa saja yang diperlukan oleh manusia guna keperluan kehidupanya, baik di dunia maupun di akhirat. Untuk mendapatkan ilmu-ilmu yang diperlukan manusia tersebut, haruslah melalui sebuah proses

\footnotetext{
${ }^{19}$ Mahmud Yunus, Kamus Arab- Indonesia, (Jakarta: Hidakarya Agung, 1989), h. 126

20 Zaki Badawi, Dictionary or Education, (Kairo: Dar al- fikr al-Arabi, 1980), h. 229

${ }^{21}$ Muhaimin, Pengembangan Kurikulum Pendidikan Agama Islam di Sekolah, Madrasah dan di Perguruan Tinggi. (Bandung: Rosda karya 2005), h. 183-184.

22 Malik Fadjar, Madrasah dan Tantangan Modernitas. (Bandung: Mizan 1998), h. 111
} 
pendidikan, dan proses pendidikan itu bisa diselenggarakan atau dilaksanakan melalui sebuah lembaga pendidikan.

Keberadaan lembaga pendidikan berdasarkan realitas yang berkembang di masyarakat Indonesia justru yang paling banyak adalah model pendidikan pesantren dan madrasah. Kata "madrsah", yang secara harfiah identik dengan sekolah agama, setelah mengarungi perjalanan peradaban bangsa, diakui telah mengalami perubahan-perubahan walaupun tidak melepaskan diri dari makna asal; sesuai dengan ikatan budayanya, yakni budaya Islam. Kehadiran madrasah di Indonesia dilatarbelakangi oleh keinginan untuk memberlakukan secara berimbang antar ilmu agama dan ilmu pengetahuan umum dalam kegiatan pendidikan di kalangan umat Islam. ${ }^{23}$ Atau dengan kata lain madrasah merupakan perpaduan sistem pendidikan pesantren dengan sistem pendidikan kolonial.

Madrasah merupakan lembaga pendidikan Islam khas milik umat Islam, dan lahir dari proses sejarah umat Islam yang panjang. Pendidikan madrasah tersebut telah digunakan oleh umat Islam untuk mempelajari berbagai ilmu untuk pengembangan kehidupan umat Islam sepanjang sejarah, baik yang berkembang di dunia Islam, terutama di wilayah Nusantara.

Madrasah sebagai lembaga pendidikan Islam, mulai dirintis dan berkembang sekitar abad V H atau abad XI M. Model pendidikan madrasah pertama kali dikenal di dunia Islam adalah pendidikan madrasah Bagdad. Madrasah ini dibangun oleh Nidzam Al Mulk ketika ia menjadi salah seorang menteri Sultan Malik Syah dari Bani Saljuk. Untuk itu madrasah ini lebih dikenal dengan sebutan madrasah Nidzamiyah. Komitmennya kepada keilmuan dan keinginnya mencerdaskan umat Islam pada masa itu, ia juga mendirikan madrasah yang sejenis di Naisabur dengan nama yang sama yaitu "Madrasah Nidzamiyah". ${ }^{24}$

\section{Manajemen Sumber Daya Manusia}

Aspek sumber daya manusia (SDM) atau ketenangan dalam madrasah adalah pelaku dan penggerak semua unsur kegiatan di madrasah. Sumber daya manusia di lembaga pendidikan madrasah meliputi tenaga pendidik (guru) dan tenaga kependidikan nonguru yang meliputi pegawai administrasi (tatausaha), laboran, pustakawan, teknisi dan pembantu pelaksana (tanaga kebersihan).

Sumber Daya Manusia juga merupakan bagian dari sistem organisasi dalam pendidikan yang terdiri dari berbagai unsur di dalamnya. Masing-masing unsur tersebut memiliki fungsi, dan saling terkait satu sama lainnya. Sebagai bagian sistem, maka yang dimaksud dengan manajeman ini adalah tindakan

${ }^{23}$ Hasbullah, Kapita Selekta Pendidikan Islam (Jakarta: PT Raja Grafindo Persada, 1996), h. 66

24 Muhammad 'Atiyah Al Abrasyi, Dasar-Dasar Pokok Pendidikan Islam. Terjemah Bustami A. Ghani. (Jakarta: Bulan Bintang, 1975), h. 92. 
perencanaan, pengorganisasian, pengarahan dan pengawasan untuk mencapai tujuan diselenggarakannya pendidikan di madrasah.

Memperhatikan konsep manajeman sebagaimana tersebut diatas, nampak jelas bahwa proses manajeman itu di dalamnya harus menampilkan fungsifungsi pokok yang dilakuakan oleh seorang pemimpin, yaitu; perencanaan (planning), pengorganisasian (organizing), kepemimpinan (leading), dan pengawasan (controlling). Oleh sebab itu, manajeman diartikan sebagai proses merencanakan, mengorganisasi, memimpin dan mengendalikan upaya organisasi dengan segala aspeknya agar tujuan organisasi tercapai secara efektif dan efisien.25 Masing-masing fungsi manajeman tersebut akan dijelaskan di bawah ini:

\section{Perencanaan (Planning)}

Mulyasa mengemukakan bahwa "perencanaan merupakan proses yang sistematis dalam pengambilan keputusan tentang tindakan yang akan dilakukan pada waktu yang akan datang." 26

Sedangkan menurut G.R Terry, sebagaiman dijelaskan oleh Sukarna, perencanaan ialah pemilihan dan penghubungan fakta-fakta serta perbuatan dan penggunaan perkiraan-perkiaraan/asumsi-asumsi untuk masa yang akan datang dengan jalan menggambarkan dan merumusakan kegitan-kegiatan yang diperlukan untuk mencapai hasil yang diinginkan.27

Perencanaan merupakan tindakan menetapkan terlebih dahulu apa yang akan dikerjakan, bagaimana mengerjakannya, apa yang harus dikerjakan, dan siapa yang mengerjakannya. Perencanaan sering juga disebut jembatan yang menghubungkan kesenjangan atau jurang antara keadaan masa kini dan keadaan yang diharapkan terjadi pada masa yang akan datang. Meskipun keadaan masa depan yang tepat itu sukar diperkirakan, karena banyak faktor luar penguasaan manusia yang berpengaruh terhadap rencana, tetapi tanpa perencanaan kita akan menyerahkan keadaan pada masa yang akan datang itu kepada kebetulankebetulan.

Dengan demikian, yang dimaksud dengan perencanaan pendidikan adalah keputusan yang diambil untuk melakukan tindakan selama waktu tertentu (sesuai dengan jangka waktu perencanaan) agar penyelenggaraan sistem pendidikan menjadi lebih efektif dan efisien, serta menghasilkan lulusan yang lebih bermutu, dan relevan dengan kebutuhan pembangunan.

25 Nanang Fattah, Landasan Manajemen Pendidikan, (Bandung: Remaja Rosdakarya, 2004). h.

${ }^{26}$ E. Mulyasa, Manajemen Berbasis Madrasah; Konsep, Strategi, Dan Implementasi, (Bandung: Rosda Karya, 2001), h. 20.

27 Sukarna, Dasar-Dasar Manajemen, (Bandung: CV. Mandar Maju, 1992),h. 10. 
Dalam kaitan ini cara-cara menyelenggarakan pendidikan baik yang bersifat formal, nonformal, maupun informal merupakan kegiatan komplementer di dalam suatu sistem pendidikan yang tunggal.

Pendidkan formal yang dimaksud yaitu sistem yang terlembaga, bertingkat dan mempunyai struktur hirarkis yang mencakup jenjang pendidikan dasar, menengah, dan tinggi. Pendidikan formal ini, merupakan sistem yang dewasa ini masih dianggap sebagai cara penyampaiaan pendidikan paling tinggi. Pendidikan nonformal yaitu kegiatan belajar secara sistematis dan teratur yang dilakukan diluar madrasah bertujuan memberikan aneka ragam kegiatan belajar yang langsung bersangkutan dengan pekerjaaan. Sedangkan pendidikan informal merupakan proses pendidikan yang tidak terorganisir dan berlangsung seumur hidup. ${ }^{28}$

\section{Pengorganisasian (Organizing)}

Organizing berasal dari kata organize yang berarti menciptakan struktur dengan bagian-bagian yang terintergrasikan sedemikian rupa, sehingga hubungannya satu sama lain terkait oleh hubungan terhadap keseluruhannya. ${ }^{29}$

Pengorganisasian dapat diartikan penentuan pekerjaan-pekerjaan yang harus dilakukan, pengelompokan tugas-tugas dan membagi-bagikan pekerjaan kepada setiap karyawan, penetapan departemen-departemen (subsistem) serta penentuan hubungan-hubungan. Pengorganisasian adalah fungsi manajeman dan merupakan suatu proses yang dinamis, sedangkan organisasi merupakan alat atau wadah yang statis. Sebagaimana dikatakan oleh Malayu:

Pengorganisasian adalah suatu proses penentuan, pengelompokkan, dan pengaturan bermacam-macam aktivitas yang diperlukan untuk mencapai tujuan, menempatkan orang-orang pada setiap aktivitas ini, menyediakan alat-alat yang diperlukan, menempatkan wewenang yang secara relatif didelegasikan kepada setiap individu yang akan melakukan aktivitas-aktivitas tersebut. ${ }^{30}$

Menurut G.R Terry sebagaimana dijelaskan oleh Malayu SP Hasibuan bahwa, pengorganisasian merupakan tindakan mengusahakan hubungan-hubungan kelakuan yang efektif antara orang-orang, sehingga mereka dapat bekerjasama secara efisien dan dengan demikian memperoleh kepuasan pribadi dalam hal melaksanakan tugas-tugas tertentu dalam kondisi lingkungan tertentu guna mencapai tujuan atau sasaran. ${ }^{31}$

${ }^{28}$ Nanang Fattah, Landasan Manajemen..., h. 50

${ }^{29}$ Malayu S.P Hasibuan, Manajemen: Dasar, Pengertian, dan Masalah. (Jakarta: CV. Haji Mas Agung), 1990, h. 118

30Ibid, 119

31 Ibid, 120 
Sedangkan menurut Harold Koontz dan Cyril O'Donnell sebagaimana dijelaskan oleh Sukarna bahwa, fungsi pengorganisasian dari manager meliputi penentuan, penghitungan kegiatan-kegiatan yang diperlukan untuk mencapai tujuan-tujuan perusahaan, pengelompokkan kegiatan-kegiatan, penempatan kelompok kegiatan-kegiatan termaksud ke dalam suatu bagian yang dikepalai oleh seorang manager, serta pelimpahan wewenang untuk melaksanakannya. ${ }^{32}$

Dari beberapa pengertian di atas, maka dapat dikemukakan aspek yang penting dari pengorganisasian, yaitu: adanya tujuan yang akan dicapai, adanya penetapan dan pengelompokkan pekerjaan, adanya wewenang dan tanggung jawab, adanya hubungan satu sama lain, dan adanya penetapan orang-orang yang akan melakukan pekerjaan.

\section{Kepemimpinan (Leading)}

Pemimpin merupakan salah satu intisari manajeman, suberdaya pokok, dan titik sentral dari setiap aktivitas yang terjadi dalam suatu organisasi. Bagaimana kreatifitas dan dinamikanya seorang pemimpin dalam menjalankan wewenang kepemimpinananya akan sangat menentukan apakah tujuan organisasi dapat tercapai atau tidak. Pemimpin yang dinamis dan kreatif maka organisasi yang dipimpinnya juga akan semakin dinamis dan aktivitas-aktivitas yang akan dilakukan akan semakin banyak. Istilah pemimpin adalah terjemahan leader/ head/ manager, yang juga disebut manajer/ kepala/ ketua/ direktur/ presiden, dan lain sebagainya, tugasnya pemimpin adalah setiap orang yang mempunyai bawahan. Pemakaian istilah ini tergantung kepada kebiasaan atau kesenangan setiap oraganisasi, jadi tidak perlu diperdebatkan. ${ }^{3}$

Kepemimpinan dapat diartikan sebagai kegiatan untuk mempengaruhi orang-orang yang diarahkan terhadap pencapaian tujuan organisasi. Sutrisno merumuskan kepemimpinan sebagai proses mempengaruhi kegiatan seseorang atau kelompok dalam usaha kearah pencapaian tujuan dalam situasi tertentu.

Sementara Soepardi mendefinisikan kepemimpinan sebagai kemampuan untuk menggerakkan, mempengaruhi, memotivasi, mengajak, mengarahkan, menasehati, membimbing, menyuruh, memerintah, melarang, dan bahkan menghukum (kalau perlu), serta membina dengan maksud agar manusia sebagai media manajemen mau berkerja dalam rangka mencapai tujuan administrasi secara efektif dan efisien. Hal tersebut menunjukan bahwa kepemimpinan sedikitnya mencakup tiga hal yang saling berhubungan, yaitu adanya pemimpin dan karekteristiknya,

32 Sukarna, Dasar-Dasar Manajemen..., h. 38-39

33Malayu S.P Hasibuan, Manajemen: Dasar..., h.42-43. 
adanya pengikut, serta adanya situasi kelompok tempat pemimpin dan pengikut berinteraksi. ${ }^{34}$

Menurut Gerungan, sebagaimana dikutip oleh Nanang Fatah, bahwa setiap pemimpin, sekurang-kurangnya memiliki tiga ciri, yaitu (1) penglihatan sosial, (2) kecakapan berfikir, (3) keseimbangan emosional. Sedangkan menurut J. Slikboer, pemimpin hendaknya memiliki sifat-sifat (1) dalam hubungan intelektual, (2) berkaitan dengan watak, (3) berhubungan dengan tugasnya sebagai pemimpin. ${ }^{35}$

Menurut Pidarta bahwa: untuk memiliki kemampuan, terutama keterampilan konsep, para kepala madrasah diharapkan melakukan kegiatan-kegiatan berikut: (1) senantiasa belajar dari pekerjaan sehari-hari terutama dari cara kerja para guru dan pegawai madrasah lainnya; (2) melakukan observasi kegiatan manajeman secara terencana; (3) membaca berbagai hal yang berkaitan dengan kegiatan-kegiatan yang sedang dilaksanakan; (4) memanfaatkan hasil penelitian orang lain; (5) berfikir untuk masa yang akan datang, dan (6) merumuskan ide-ide yang dapat diuji coba. ${ }^{36}$

\section{Pengawasan (Controlling)}

Kata control dalam bahasa Indonesia terjemahannya belum sama, ada yang menterjemahkannya dengan kata pengawasan ada pula dengan kata pengendalian. Pengawasan atau pengendalian dapat diartikan sebagai upaya untuk mengamati secara sistematis dan berkesinambungan; merekam; memberi penjelasan, petunjuk, pembinaan dan meluruskan berbagai hal yang kurang tepat; serta memperbaiki kesalahan. Pengawasan, merupakan kunci keberhasilan dalam keseluruhan proses manajeman, perlu dilihat secara komprehensif, terpadu, dan tidak terbatas pada hal-hal tertentu. ${ }^{37}$

Dalam pelaksanaan pengembangan madrasah, partisispasi SDM sangatlah diperlukan dan bahkan menepati posisi strategis sebagai pelaku utama dalam menjalankan berbagai program pengembangan mutu madrasah. Demikian juga sebaliknya tanpa adanya dukungan SDM yang andal, nampaknya keberadaan madrasah sangat sulit untuk bisa berkembang dengan baik.

Pengembangan sumber daya manusia (SDM) di madrasah merupakan suatu proses yang dilakukan secara sadar, terarah, terprogram dan terpadu, bertujuan untuk meningkatkan kualitas hidup manusia (pengelola madrasah) agar dapat mengelola lembaga pendidikan Islam tersebut secara baik, sehingga madrasah tersebut menjadi bermutu dan unggul.

34 E. Mulyasa, Manajemen Berbasis Madrasah.., h.107-108.

${ }^{35}$ Nanang Fattah, Landasan Manajemen...,.h. 89.

36Ibid,h. 126-127.

37E. Mulyasa, Manajemen Berbasis Madrasah...,. h. 21. 
Pengembangan sumber daya manusia di madrasah ternyata bisa dilakukan oleh berbagai pihak, seperti dilakukan oleh diri sendiri, dilakukan oleh pihak madrasah yang dalam hal ini dilakukan berdasarkan perencanaan organisasi yang disusun bersama, maupun dilakukan oleh pihak lain yang ikut bertanggung jawab dalam penyelenggaraan pendidikan di madrasah tersebut.

Pengembangan SDM di ketiga MTs. tersebut didasarkan pada; 1). Evaluasi diri dan analisis kebutuhan. 2). Menyusun program perencanaan pengembangan sumber daya Pendidik . 3). Melaksanakan program perencanaan pengembangan sumber daya Pendidik . 4). Melakukan Evaluasi pelaksanaan pengembangan sumber daya Pendidik .5). Target pencapaian pengembangan sumber daya Pendidik .6). Orientasi pengembangan sumber daya Pendidik bagi madrasah.

Strategi pengembangan SDM Pendidik dimulai dari proses "buy" (rekrutmen) dan "make" (pembinaan/pengembangan). Di MTs Mathla'ul Anwar Islamiyah Cinta Mulya rekrutmen mandiri, yang dimulai dari seleksi calon tenaga guru. Di MTs Hidayatul Mubtadi' in Sidoharjo Jati Agung dan MTs Al Ishlah Sukadamai Natar. Namun penerapan teori pengembangan Sumber Daya Manusia di ketiga lembaga tersebut belum cukup maksimal namun sudah dapat menghasilkan Mutu lulusan yang cukup baik.

Bentuk kegiatan dalam rangka pembinaan/pengembangan SDM yang bermutu di tiga lembaga tersebut antara lain adalah; 1). Meningkatkan wawasan pengetahuan para Pendidik melalui penyediaan fasilitas kegiatan, seperti studi lanjut, diskusi rutin antar guru, seminar, simposium, kolokium, workshop, pembentukan kelompok kerja guru (KKG), kunjungan antar kelas, kunjungan antar lembaga, dan kerja sama dengan lembaga kependidikanan lainnya yang menguntungkan. 2). Membangun SDM yang memiliki sikap komitmen tinggi untuk berjuang (ber-jihad) dengan memajukan lembaga melalui berbagai kegiatan, seperti; disiplin dan menjalankan tugas, pro-aktif terhadap semua perubahan, mendukung semua kegiatan yang disepakati, menjadi figur yang bisa diteladani dalam bekerja dan berperilaku, selalu aktif dan inovatif dalam mengembangkan profesi. 3). Membangun SDM yang memiliki keputusan tinggi dan menjalankan tugas, hal ini telah dilakukan melalui pemberian kesejahteran yang cukup, menyediakan fasilitas pembelajaran yang memadai, dan lain sebagainya.

Di MTs Mathla'ul Anwar Islamiyah Cinta Mulya intensitas kegiatan dilakukukan oleh pihak lembaga, oleh pihak kemenang dan komite madrasah. Di MTs Hidayatul Mubtadi'in Sidoharjo Jati Agung intensitas kegiatan difasilitasi oleh pihak lembaga, kesadaran diri sendiri, dan Yayasan. Di MTs Al Ishlah Sukadamai Natar intensitas kegiatan difasilitasi oleh pihak lembaga, kesadaran diri sendiri, dan yayasan. 


\section{Simpulan}

Pengembangan sumber daya manusia (SDM), baik pendidik maupunTenaga Kependidikan yang telah dilakukan ketiga madrasah, nampaknya hampir cocok dan atau mendukung teori yang dikemukakan oleh Andre E. Sikulayang telah dijelaskan pada bab kajian teori, yakni dalam pengembangan SDM mencangkup lima komponen di dalamnya, yaitu; tujuan sumberdaya manusia, perencanaan organisasi, pengauditan sumber daya manusia, peramalan sumber daya manusia.

Pada aspek pendekatan dalam pengembangan SDM, ketiga madrasah tersebut menggunakan pendekatan yang sama, yaitu dengan, menggunakan dua pendekatan sekaligus yaitu pendekatan "buy" yang berarti rekrutmen/penarikan dan "make" yang berarti pembinaan/pengembangan untuk meningkatkan mutu SDM. Hal ini mendukung dan atau cocok dengan teori yang di kemukakan oleh Alwi. S. sebagai mana dijelaskan pada bab II.

Sedangkan pada aspek model atau tipe pengembangan sumberdaya manusia di tiga madrasah tersebut cenderung menggunakan dan atau mendukung teori Sonnenfeld dan Maury Peipert, sebagaimana di jelaskan oleh Greer C. R. dalam Strategi and Human Resources. A. General Managerial Perspective (1995), yakni tipe "academy", yaitu mengembangkan dua mode / tipe dari tipe "Club dan tipe Baseball team". Model/tipe academy menekankan bahwa dalam pengembangan SDM dimulai dari awal, yaitu dari proses rekrumen sampai dengan melakukan pembinaan, pelatihan dan pendidikan, serta kegiatankegiatan lain yang dapat menunjang karir dan mutu SDM. Namun demikian untuk bisa mencapai itu perlu menggunakan low cost dan cost controlling sebagaimana dijelaskan dalam tipe club, artinya menekan biaya rendah tetapi mendapat hasil yang memuaskan.Di samping itu, pengembangan SDM juga diperlukan adanya produk baru (inovasi) yang selalu up to date sebagai dijelaskan dalam tipe baseball team, artinya pengembangan SDM selalu diorentasikan pada sebuah inovasi dalam kinerja maupun produknya.

Dalam kaitan dengan kebutuhan pelatihan dan pengembangan, ketiga madrasah ini menggunakan dan atau mendukung teori analisis dari Goldestein dan Buxton, yaitu menggunakan tiga analisis kebutuhan yaitu pelatihan dan pengembangan, yaitu; (1) Organization analysis, yakni; menganalisisi tujuan organisasi, sumberdaya yang ada, dan lingkungan organisasi sesuai dengan keyakinan., (2) Job or task analysis, yakni; analisis terhadap pekerjaan dan tugas sebagai dasar untuk mengembangkan program pelatihan analisis job. Ini dimaksudkan untuk membantu Tenaga Kependidikan meningkatkan pengetahuan, skill, dan sikap terhadap suatu pekerjaan. (3) Person analiysis yakni analisis terhadap pekerjaan sumberdaya manusia dan mengfokuskan pada identifikasi khusus kebutuhan pelatihan bagi tenaga yang bekerja pada job-nya. Kebutuhan pelatihan Tenaga Kependidikan dapat dianalisis secara individu dan kelompok. Analisis kebutuhan individu dari pelatihan dapat dilakukan dengan 
cara observasi oleh supervisor (kepala MTs), evaluasi keterampilan, kartu kontrol kualitas, dan keterampilan Tenaga Kependidikan. Kebutuhan kelompok dari pelatihan dapat diprediksi dengan pertimbangan informasi dan observasi kepada kepala MTs maupun kepala waka.

\section{Referensi}

Ahmad Fatah Yasin, Dimensi-dimensi Pendidikan Islam, (Malang: UIN Press, 2008) Ahmad Tafsir, Ilmu Pendidikan Dalam Perspektif Islam. ( Bandung: Remaja Rosydakarya, 1992)

Departemen Agama RI, Al Qur'an dan Terjemahnya. (Surabaya: Mahkota, Edisi Revisi, 2013)

E. Mulyasa, Manajemen Berbasis Madrasah; Konsep, Strategi, Dan Implementasi, (Bandung: Rosda Karya, 2001)

Hasbullah, Sejarah Pendidikan Insilam di Indonesia:Lintasan Sejarah Pertumbuhan dan perkembangan, (Jakarta:Raja Grafindo persada, 1996)

Hasbullah, Kapita Selekta Pendidikan Islam (Jakarta: PT Raja Grafindo Persada, 1996)

Ingemar Fagerlind \& Lawrence J. Saha, Education and National Develoment: A Comperative Perspektive (New York : Pergamon Press,1983)

${ }^{1}$ Karel A.Steenbrink, Pesantren, Madrasah, Sekolah: Pendidikan Islam Dalam Kurun Modern (Jakarta : LP3ES, 1986)

Mahmud Yunus, Kamus Arab- Indonesia, (Jakarta: Hidakarya Agung, 1989)

Malayu S.P Hasibuan, Manajemen: Dasar, Pengertian, dan Masalah. (Jakarta: CV. Haji Mas Agung), 1990

Malik Fadjar, Madrasah dan Tantangan Mordernitas (Bandung: Mizan, 1998)

Malik Fadjar, Madrasah dan Tantangan Modernitas. (Bandung: Mizan 1998)

Malik Fadjar, Tantangan dan Peran Umat Islam Dalam Menyongsong Abad XXI. (Surabaya: Makalah IAIN Sunan Ampel,1995)

Mastuhu, Dinamika Sistem Pendidikan Pesantren (Jakarta: INIS, 1994)

Muhaimin, Konsep Pendidikan Islam: Sebuah Telaah Komponen Dasar Kurikulum. (Solo: Ramadhoni, 1991)

Muhaimin, Pengembangan Kurikulum Pendidikan Agama Islam di Sekolah, Madrasah dan di Perguruan Tinggi. (Bandung: Rosda karya 2005), hal. 183-184.

Muhammad 'Atiyah Al Abrasyi, Dasar-Dasar Pokok Pendidikan Islam. Terjemah Bustami A. Ghani. (Jakarta: Bulan Bintang, 1975)

Nanang Fattah, Landasan Manajemen Pendidikan, (Bandung: Remaja Rosdakarya, 2004)

Sukarna, Dasar-Dasar Manajemen, (Bandung: CV. Mandar Maju, 1992)

Undang-undang Nomor 20 tahun 2003. tentang sistem pendidikan Nasional, (Bandung: Citra Umbara, 2003), Pasal 13.

Yahudi Cohen, School and Civilationl States (New York: Internasional Texbook Company Pergamon Press,1970)

Zaki Badawi, Dictionary or Education, (Kairo: Dar al- fikr al-Arabi, 1980) 